\title{
CLINICAL EFFECTS OF THE USE OF PNEUMATIC TOOLS
}

BY

\author{
DONALD HUNTER, A. I. G. MCLAUGHLIN and KENNETH M. A. PERRY
}

From the Department for Research in Industrial Medicine (Medical Research Council), The London Hospital, and the University of Sheffield and Factory Department of the Ministry of Labour and National Service

Pneumatic or ' wind-driven' tools were first used in French mines as early as 1839 but they were not used extensively in other industries until 1883 . Now they are used in many industries and for many purposes. The tools, which vary in weight from 3 to $30 \mathrm{lb}$., are made up of (1) a distribution box supplied with compressed air; (2) a reciprocating piston; and (3) the tool proper (fig. 1). The compressed air acts alternately at each end of the piston and thus produces a vibratory effect. Pneumatic drills work similarly but they have an additional mechanism which translates the reciprocating movement into a rotatory one. The speed of the piston in the different types of tool varies from 250 to 6000 strokes per minute, In general the heavier the tool the slower the vibration rate. The weights and vibration rates of the tools used for various purposes are given in Table 1. It will be seen that heavy tools are used in mines, quarries and in road-making. In shipbuilding and repairing and in boiler shops medium-sized tools are used for hot riveting, cold copper staying and caulking. Similar tools with a rotatory movement are used for drilling. In foundries medium-sized tools with a chisel end are used for dressing or fettling metal castings, and tools of comparable weight are used by stonemasons for dressing stone. Much lighter pneumatic tools are used in the motor and aircraft industries and for riveting tanks and cisterns. Light tools, about $4 \mathrm{lb}$. in weight, are used in the scaling of boiler tubes. Heavy tools such as rivet cutters are mounted on supports but in most instances the worker holds the tool with both hands ; he supports it with the left hand and holds the trigger with the right (fig. 2). A glove is worn on the left hand to protect it from the heat engendered by the friction set up by the movement of the piston and chisel, but as a rule no glove is worn on the right hand. If the tool is working well air only escapes through the exhaust, which can be directed away from the man's hands. Sometimes, however, there is a leak and the right hand is exposed to a stream of cold air. In order to get into awkward corners the position of the hands is reversed-' right and left ' as it is called in the shipbuilding trade.

\section{White Fingers}

Workers, who use pneumatic tools, suffer from vascular disturbances which produce a local anaemia or pallor of the fingers, making them stiff and awkward and in severe cases the symptoms may prevent the men from working or cause them to seek other employment. It must be remembered that many occupations involving the use of pneumatic tools are carried on out-of-doors and this phenomenon of 'white fingers' must be clearly differentiated from the effects which cold weather would have on the fingers of any normal individual. Characteristic 'white fingers' or 'dead hand' of

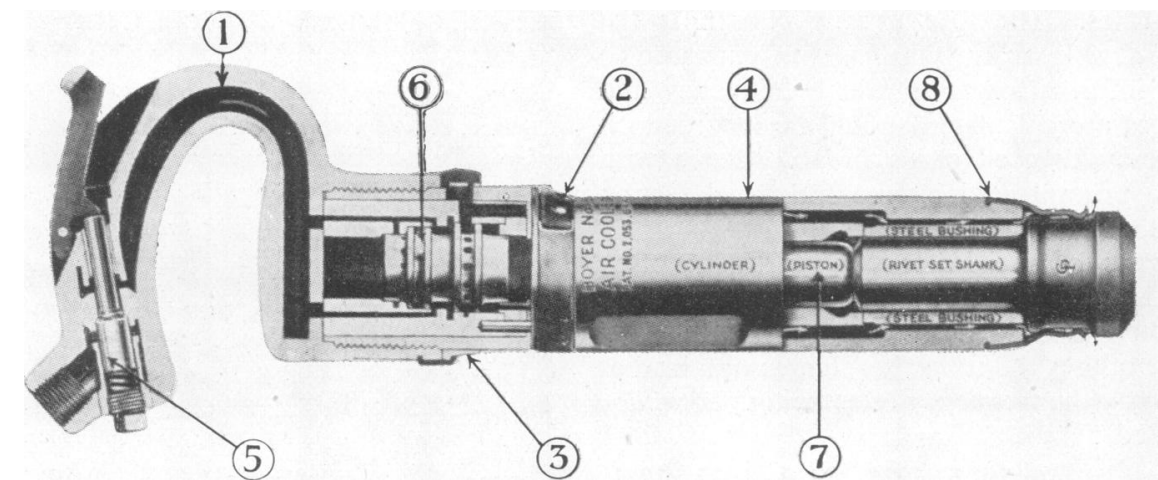

FIG. 1.-Cross-section of a pneumatic riveting hammer, showing (1) the handle; (2) the exhaust deflector adjustable to any radial position; (3) locking ring surrounding the cylinder and preventing handle from unscrewing or loosening; (4) heat treated steel cylinder threaded into handle; (5) throttle valve heat-treated to resist wear and operating in a replaceable steel bushing; (6) hollow cylindrical valve; (7) heat-treated steel piston; (8) spring clip set retainer. The areas with the white arrows indicate two of the four ports which carry the cooling currents of exhaust air down the length of the cylinder to its nose end and out past the rivet set head. (By courtesy of the Consolidated Pneumatic Tool Co., Ltd.) 
TABLE 1

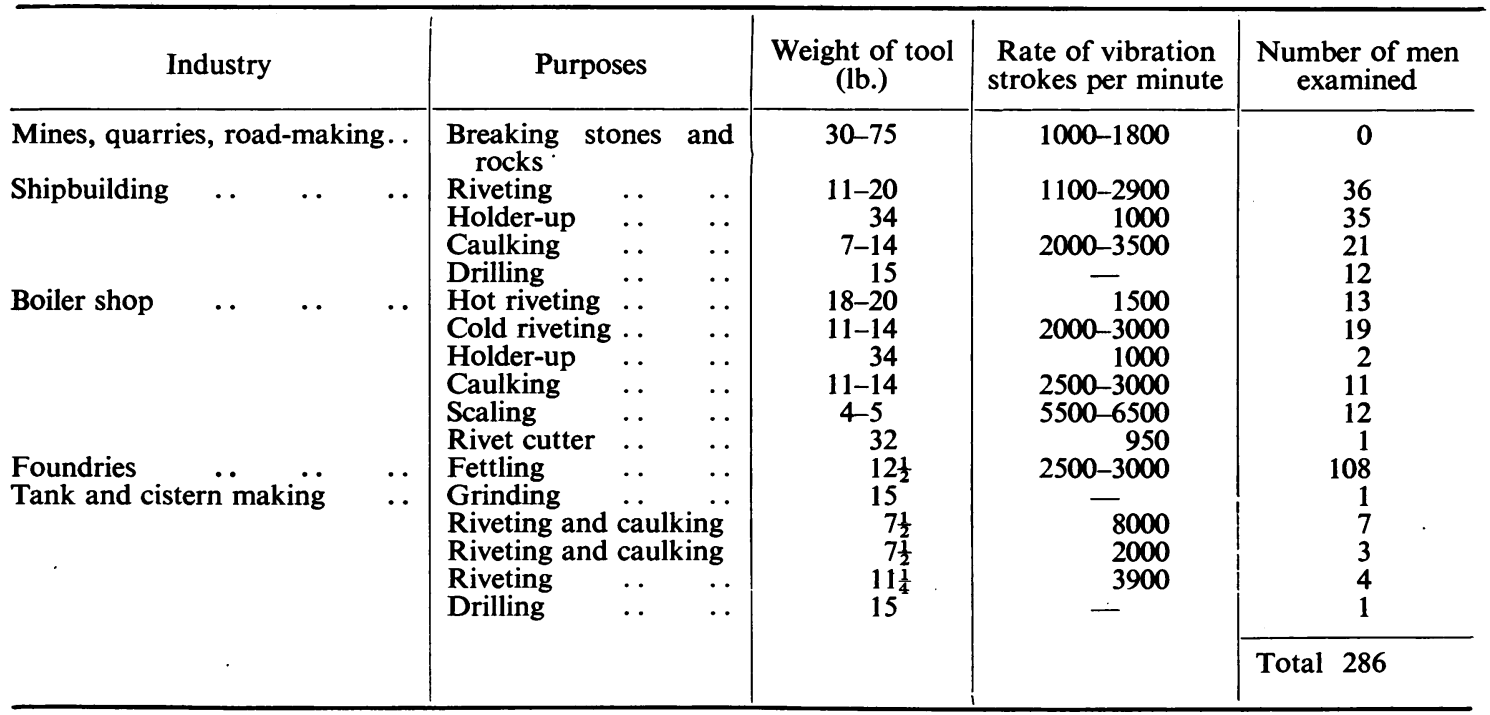

pneumatic tool workers are mostly confined to the left hand in right-handed workers and to the right hand in left-handed workers. In the series of cases of the investigation described later 3 left-handed riveters and 2 left-handed fettlers were found. The hand which holds the tool bears the brunt of the vibration. Sometimes the men rest the tool, mostly on the middle, ring and little fingers, and use the index finger and thumb as guide. In these circumstances it is found that the index finger and thumb escape. When symptoms are severe the men have to stop

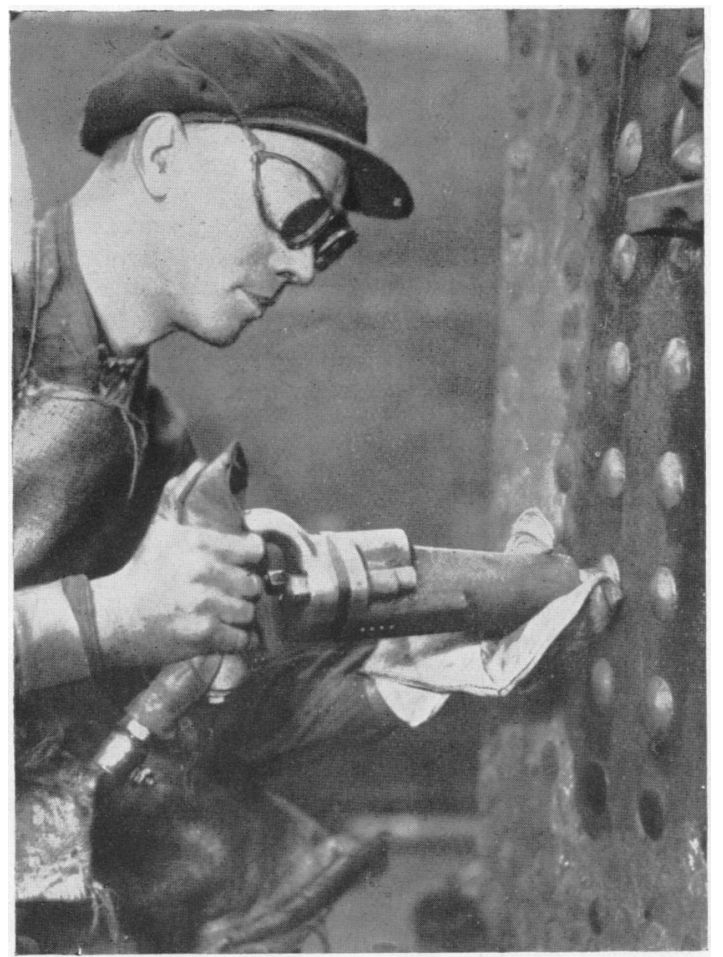

FIG. 2.-Illustrates how riveter holds tool. work and they find that by rubbing or warming the fingers the sensation returns after periods ranging from a quarter of an hour to two hours. There are no stages of hyperaemia or cyanosis such as occur in Raynaud's disease. The symptoms are most pronounced and certainly aggravated by cold weather and by washing the hands in cold water, but they have been seen to occur on a hot day in mid-summer. When the syndrome of 'white fingers' has been established it tends to recur on exposure to cold for some years after the worker has stopped using pneumatic tools.

Case histories of four men from the group examined in this investigation are given to demonstrate certain aspects of the syndrome.

Case 1. An example of a man who had to stop using pneumatic tools.

A. B., aged 40 . $12 \frac{1}{2}$ years before examination, he started work as a copper stayer using a hammer weighing $12 \mathrm{lb}$. with a frequency of 2300 vibrations a minute. He also wore a glove on the left hand. After he had been working for 2 years he noticed his fingers would go white.

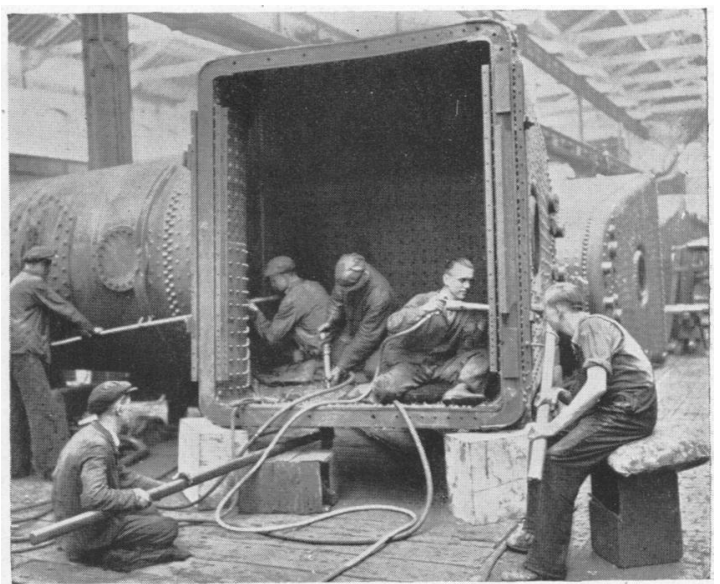

FIG. 3.-Riveters at work. 
The first one involved was the index finger on the left hand: the whiteness was associated with paraesthesiae. Gradually the right hand became involved and soon all the fingers on both hands would go white. He found the hands very awkward to use and had difficulty in doing up buttons. If often took two hours for the sensation to return. At the start the syndrome occurred only in winter, but after 4 years it occurred in summer as well. After 6 $\frac{1}{2}$ years' work with the hammer he had to give up this work on account of the symptoms, and is now working as a labourer in the boiler shop.

Case 2. An example of a young caulker with the fully developed syndrome.

I. C., aged 29. For 14 years he had worked as a caulker with a tool having a vibration frequency of 2850 per minute, and weighing $11 \frac{1}{4} \mathrm{lb}$. After he had used the caulking chisel for 4 years he started to have white numb fingers: first the left index finger and then spreading to involve all the fingers. The syndrome usually appeared soon after he started work, but it sometimes occurred on Sundays when he was not working. After warming or rubbing for 15 minutes the circulation returned. After he was questioned, he washed his hands in cold water on a hot August afternoon and it was observed that all his fingers went completely white with a sharp line of demarcation where they joined the hand. Sensation to pin prick and light touch was much impaired in these fingers. The phenomenon took 15 minutes to disappear.

Case 3. An example of a left-handed riveter with the syndrome in the right hand only.

A. S., aged 31. For 16 years he had been a riveter, using a hammer with a vibration frequency of 1400 per minute and weighing $19 \frac{1}{2} \mathrm{lb}$. He was left-handed. After he had been at the work for 7 years he noticed that after starting work the index and third finger of his right hand, that is the one that supported the tool, went white and developed pins and needles. These phenomena would pass away after rubbing or warming for 10 minutes.

Case 4. An example of a fettler with Dupuytren's contracture and the 'white finger' syndrome only slightly present.

J. E., aged 47. For 18 years he had worked as a fettler, using a chisel with a vibration frequency of 2650 per minute, and weighing $121 \mathrm{lb}$. He complained of having cold hands during the winter, but had never had any numbness or deadness of the fingers. On examination he had Dupuytren's contracture of the right palmar aponeurosis, and the skin of the right hand was colder than the left. There was a sharply demarcated area of cold skin of the right hand which appeared to be limited by a straight line round the wrist, with the exception of an area of warm skin extending on to the dorsum of the hand between the thumb and index finger.

Maria Seyring (1930) studied 189 cast iron fettlers in a large metallurgical works where pneumatic tools were used, and reported that 92 complained of white fingers. In 60 of these 92 cases the symptoms were restricted to the left hand, in 8 principally to the left hand, in 5 to the right hand only, in 8 principally to the right hand, whereas both hands were affected in 11 cases. The symptoms came on after about 2-3 years' work and the percentage of positive cases increased with the length of the working history. The details are given below:-

\begin{tabular}{lrrccc} 
& & \multicolumn{4}{c}{ Years of work } \\
\multicolumn{1}{l}{$\begin{array}{l}\text { Examination } \\
\text { Negative }\end{array}$} & 2 & $2-5$ & $3-10$ & Above 1) \\
$\begin{array}{l}\text { Positive } \\
\text { Per cent. positive }\end{array}$ & 25 & 13 & 31 & 28 \\
$\begin{array}{l}\text { cases .. } \\
\text {.. }\end{array}$ & 4 & 12 & 37 & 42 \\
& & & 48 & 55 & 61
\end{tabular}

She suggests that the hardness of the material is an important factor in the etiology. Among men who had been working for 3 years or more, 61 out of 72 working on hard material were affected, whereas only 16 out of 31 working on soft material, 2 out of 10 riveters, and 2 out of 27 men using a pneumatic tool to compress sand into moulds developed white fingers. Out of 35 fettlers of hard castings with upwards of 10 years' working experience, 31 were affected. Another interpretation, however, could be placed on these findings because fettlers use tools with a vibration rate between 2000 and 3000 strokes per minute, whereas the riveters and compressors use tools with a slower vibration rate. Hunt (1936) records 7 cases of white fingers occurring in riveters and he suggested that the cause of the condition is the vibration transmitted from the end of the tool grasped in the left hand. He emphasized that the body and the handle of the tool vibrate less than the striking end. Although he regards the vibration of the tool as the fundamental cause of the condition he thinks that cold is the factor which precipitates an attack. He also points out that, owing to the weight of the instrument and the cramped positions.in which these men sometimes work, they often change hands and then the right hand may be affected as severely as the left. McLaren (1937), who examined a group of 20 men engaged on pneumatic riveting, agreed with Hunt's findings. Teleky (1927) gave an account of a case in which the circulatory changes were so severe that gangrene developed in the left little finger which had to be amputated; and Bennett, Waine and Bauer (1942) have observed gangrene of the finger tips in a pneumatic hammer worker. Junghaus (1937) demonstrated arterio-venous thrombosis histologically and Barker and Hines (1944) showed by means of thoratrast that the ulnar artery was obstructed in the case of a pneumatic tool worker who complained of white fingers.

In 1930 'dead hand' also occurred among operatives who used pounding-up machines in the manufacture of boots and shoes. This was a vibrating machine and the workers stated that their fingers felt dead on starting work in the morning, but that after treating about 36 pairs of shoes at the machine the numbness of the fingers was replaced by a tingling sensation, followed by a return to normal. The disability made its appearance during the first year of work and persisted even after the job had been given up. Middleton considered that the symptoms were attributable to the pressure of the tool which impeded the circulation of the blood in the fingers. This machine is no longer used and it is therefore not possible to make further investigations.

We have examined 286 men who have been engaged for varying periods in the use of different kinds of pneumatic tools (Table 2). It will be seen that in varying percentages of the different groups of workers who use pneumatic tools the phenomenon of white fingers was found. In riveters for instance, 48 cases out of 78 had white fingers, but it will be observed that in those men who used a tool which had a vibration rate of less than 2000 strokes per minute, there were 23 cases out of 43 (53.5 per cent.), but in those who used a tool which vibrated between 2000 and 3000 times per minute 20 cases out of 27 (74 per cent.) had the condition. Again, among caulkers who use tools which vibrate 
TABLE 2

WHITE FINGERS

\begin{tabular}{|c|c|c|c|c|c|c|c|c|c|c|c|c|c|c|c|c|c|c|}
\hline \multirow{2}{*}{\multicolumn{2}{|c|}{$\begin{array}{l}\text { Occupation } \\
\text { and vibration } \\
\text { frequency } \\
\text { of tool }\end{array}$}} & \multirow{2}{*}{ Total } & \multicolumn{6}{|c|}{$\begin{array}{l}\text { Number years employed } \\
\text { with pneumatic tools }\end{array}$} & \multirow{2}{*}{$\begin{array}{c}\text { Number } \\
\text { with } \\
\text { white } \\
\text { fingers }\end{array}$} & \multirow{2}{*}{ L. } & \multirow{2}{*}{ R. } & \multirow{2}{*}{ Both } & \multicolumn{6}{|c|}{$\begin{array}{c}\text { Years before onset of } \\
\text { symptoms }\end{array}$} \\
\hline & & & $\begin{array}{c}\text { Under } \\
2\end{array}$ & $2-5$ & $6-10$ & $11-$ & $16-$ & $\begin{array}{c}\text { Over } \\
20\end{array}$ & & & & & $\begin{array}{l}\text { Under } \\
2\end{array}$ & $2-5$ & $6-10$ & $11-$ & $16-$ & $\begin{array}{l}\text { Over } \\
20\end{array}$ \\
\hline $\begin{array}{l}\text { Riveters- } \\
\text { Under } 2000 \\
2000-3000 \\
\text { Over } 3000 \\
8000\end{array}$ & $\begin{array}{l}\ldots \\
\cdots \\
\cdots\end{array}$ & $\begin{array}{r}43 \\
27 \\
4 \\
4\end{array}$ & $\begin{array}{r}12 \\
5 \\
- \\
-\end{array}$ & $\frac{2}{2}$ & $\begin{array}{l}8 \\
\frac{2}{2}\end{array}$ & $\begin{array}{r}5 \\
10 \\
1 \\
-\end{array}$ & $\begin{array}{r}11 \\
6 \\
-1\end{array}$ & $\begin{array}{l}5 \\
4 \\
1 \\
1\end{array}$ & $\begin{array}{r}23 \\
20 \\
3 \\
2\end{array}$ & $\begin{array}{r}5 \\
4 \\
1\end{array}$ & $\begin{array}{r}8 \\
1 \\
2 \\
-\end{array}$ & $\begin{array}{r}10 \\
15 \\
1 \\
1\end{array}$ & $\begin{array}{r}6 \\
10 \\
1 \\
-\end{array}$ & $\begin{array}{l}6 \\
3 \\
1 \\
2\end{array}$ & $\begin{array}{r}7 \\
4 \\
1 \\
-\end{array}$ & $\begin{array}{r}3 \\
1 \\
- \\
-\end{array}$ & $\begin{array}{l}-1 \\
-\end{array}$ & $\frac{\overline{1}}{-}$ \\
\hline $\begin{array}{r}\text { Caulkers- } \\
2000-3000 \\
8000\end{array}$ & $\begin{array}{l}\cdots \\
\cdots\end{array}$ & $\begin{array}{r}33 \\
3\end{array}$ & 6 & -3 & 5 & $\begin{array}{l}8 \\
1\end{array}$ & $\begin{array}{l}3 \\
1\end{array}$ & $\begin{array}{l}8 \\
1\end{array}$ & 27 & 6 & $\begin{array}{l}4 \\
-\end{array}$ & 17 & 4 & 11 & -6 & $\frac{4}{-}$ & - & 1 \\
\hline $\begin{array}{l}\text { Fettlers- } \\
2500-3000\end{array}$ & . & 108 & 6 & 24 & 37 & 21 & 12 & 8 & 77 & 58 & 14 & 5 & $25^{*}$ & $15^{*}$ & $11 *$ & $5^{*}$ & $1 *$ & $1^{*}$ \\
\hline $\begin{array}{l}\text { Scalers- } \\
6000 \ldots\end{array}$ & .. & 12 & 3 & 1 & - & 3 & 1 & 4 & - & - & - & - & - & 一 & - & - & - & - \\
\hline $\begin{array}{c}\text { Holders-up- } \\
1000 \ldots \\
\text { Hand } \ldots\end{array}$ & $\begin{array}{l}. \\
\cdots\end{array}$ & $\begin{array}{r}9 \\
28\end{array}$ & $\begin{array}{l}5 \\
8\end{array}$ & $\begin{array}{l}1 \\
5\end{array}$ & $\begin{array}{l}1 \\
3\end{array}$ & $\overline{6}$ & $\begin{array}{l}1 \\
4\end{array}$ & $\begin{array}{l}1 \\
2\end{array}$ & $\begin{array}{l}1 \\
4\end{array}$ & 1 & - & $\overline{4}$ & 1 & $\overline{1}$ & $\overline{2}$ & $\overline{1}$ & - & 二 \\
\hline Drillers .. & . & 13 & 2 & 2 & 4 & 2 & - & 3 & 4 & 1 & 3 & - & 1 & 1 & - & 1 & 1 & - \\
\hline Grinders & .. & 1 & 1 & - & - & - & - & - & - & - & - & - & - & - & - & - & - & - \\
\hline $\begin{array}{l}\text { Rivet cutters- } \\
980 \quad \ldots\end{array}$ & . & 1 . & 1 & - & - & - & - & - & - & - & - & - & - & - & - & - & - & - \\
\hline Total & . & 286 & 49 & 40 & 62 & 57 & 40 & 38 & 161 & 76 & 32 & 53 & 48 & 40 & 31 & 15 & 3 & 3 \\
\hline
\end{tabular}

* These figures apply to 78 of 108 fettlers; figures for the remaining 30 are not available.

between 2000 and 3000 times per minute, 27 cases out of $33(81.8$ per cent.) had white fingers, and in fettlers who use tools of similar vibration rates there were 77 cases out of $108(71 \cdot 3$ per cent.). By contrast, out of 9 ' holders-up' who are in contact with tools which vibrate at 1000 times per minute, only 1 had white fingers, and in 12 scalers whose tools vibrate at 6000 strokes per minute there was no case of white fingers.

Apart from the vibration rates of the tools the hardness or softness of the material worked appears to have some bearing on the development of white fingers. Caulkers and cold copper stayers who work on hard material appear to be most subject to the trouble, whereas hot riveters who, as the term implies, work on red-hot rivets which are softer than cold metal, are rather less subject to the syndrome. The tools which they use also vibrate at somewhat slower rates than those of the cold riveters. Other workers either use heavier instruments with a much slower rate of vibration and often work intermittently, or use lighter tools with a much faster vibration rate on lighter and softer work. Neither of these two groups seems to be prone to the condition.

In our series of cases low air temperatures, as in Hunt's cases, appeared to be the precipitating factor in the attacks. Many of these men, however, work out-of-doors in the winter in conditions under which any individual might develop chilblains. The escape of compressed air from the tools also produces cold and although the stream of air is usually directed away from the hands of the worker it does greatly cool the instrument which in cold weather may even have a collection of ice around the exhaust valve. It is unlikely that cold is the most important factor in the development of white fingers even though the symptoms are aggravated by and are always most pronounced in cold weather. The left hand is the one usually affected and this is the one farthest away from the exhaust valve, and it is in contact with that part of the instrument made hot by the vibrations. Mills (1942) and Cummins (1940) have brought forward evidence from the West Coast of America and from Ireland that a tool vibration of 2500 strokes a minute is the critical level for the onset of white fingers. Our experience leads us to believe that this theory is probably correct. The symptoms do not produce constitutional changes which would prevent a man attending at his place of work. There is nevertheless a real disability which will prevent him working until the circulation returns to his hand. In 51 cases among the 75 riveters and caulkers this took $\frac{1}{2}$ hour or less, in 17 cases one hour, in 6 cases 2 hours, and in one case more than 2 hours. It results in stiffness and loss of sensation in the fingers with an inability to perform fine movements. In some instances the symptoms may be so bad, and the attacks so frequent, that a man may have to find other work. In our series 3 men were so affected and they had to change their trade. 
Many methods of prevention of this syndrome have been suggested. The compressed air which enters the tool near the handle could be artificially warmed if the air pipe passed through a local heater, but since it is not usually the hand which holds this part of the tool which is affected, it is doubtful if this would be beneficial. Shock absorbing pads of sorbo rubber have been incorporated in the palms of the leather gauntlets which these men wear, but they do not appear to have reduced the incidence of the syndrome. Similar pads might be fixed to the handle of the machine itself, or a type of handle could be attached by a strong spring to the barrel of the instrument so that vibration on the palm of the hand is reduced to a minimum. All these suggestions, however, neglect the fact that the frequency of the vibration is the probable cause of the syndrome, and it seems that if the frequencies between 2000 and 3500 were avoided in constructing the tools, the incidence of white fingers would be very substantially reduced.

\section{Areas of Decalcification of the Bones of the Carpus}

Brailsford (1934 and 1936) showed that on X-ray examination small areas of decalcification of the bones of the carpus were found in pneumatic tool workers, and McLaren (1937) selected a group of 45 workers who had symptoms of white fingers and x-rayed the wrists of 31 of them. He also demonstrated the presence of these 'bone cysts' or areas of localized absorption occurring in the carpal bones, and in the heads of the second metacarpals. He thought that these areas were most prominent to those men who had used tools with a vibratory frequency of 2300 strokes a minute, and believed

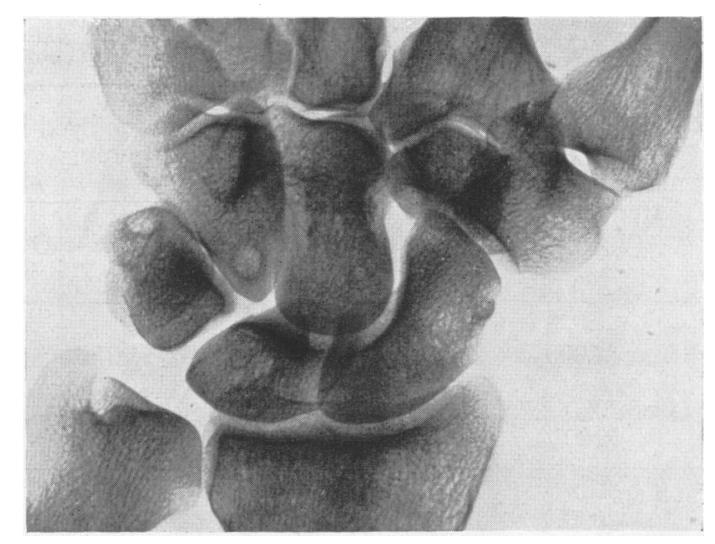

Fig. 4.-X-ray of wrist showing areas of decalcification.

that their continued use would cause extension of the osteoporosis and the risk of a pathological fracture. In our 286 cases similar radiographic transparent areas were found in the carpal bones in 148 cases (51.5 per cent.) (Table 3 ) (fig. 4). They were more common in hand holders-up (18 cases out of 28) than in any other group. The term ' hand' holder-up has been used to differentiate the men who use a simple ' dolly' for holding up, from those who use a pneumatic tool with a vibration rate of 1000 a minute. The high incidence in this group suggests that constant jarring as opposed to rhythmical vibration might play some part in the causation. The cysts were seen in 45 out of 78 riveters; in 18 of 36 caulkers; in 51 of 108 fettlers;

TABLE 3

AREAS OF DECALCIFICATION OF BONES OF CARPUS

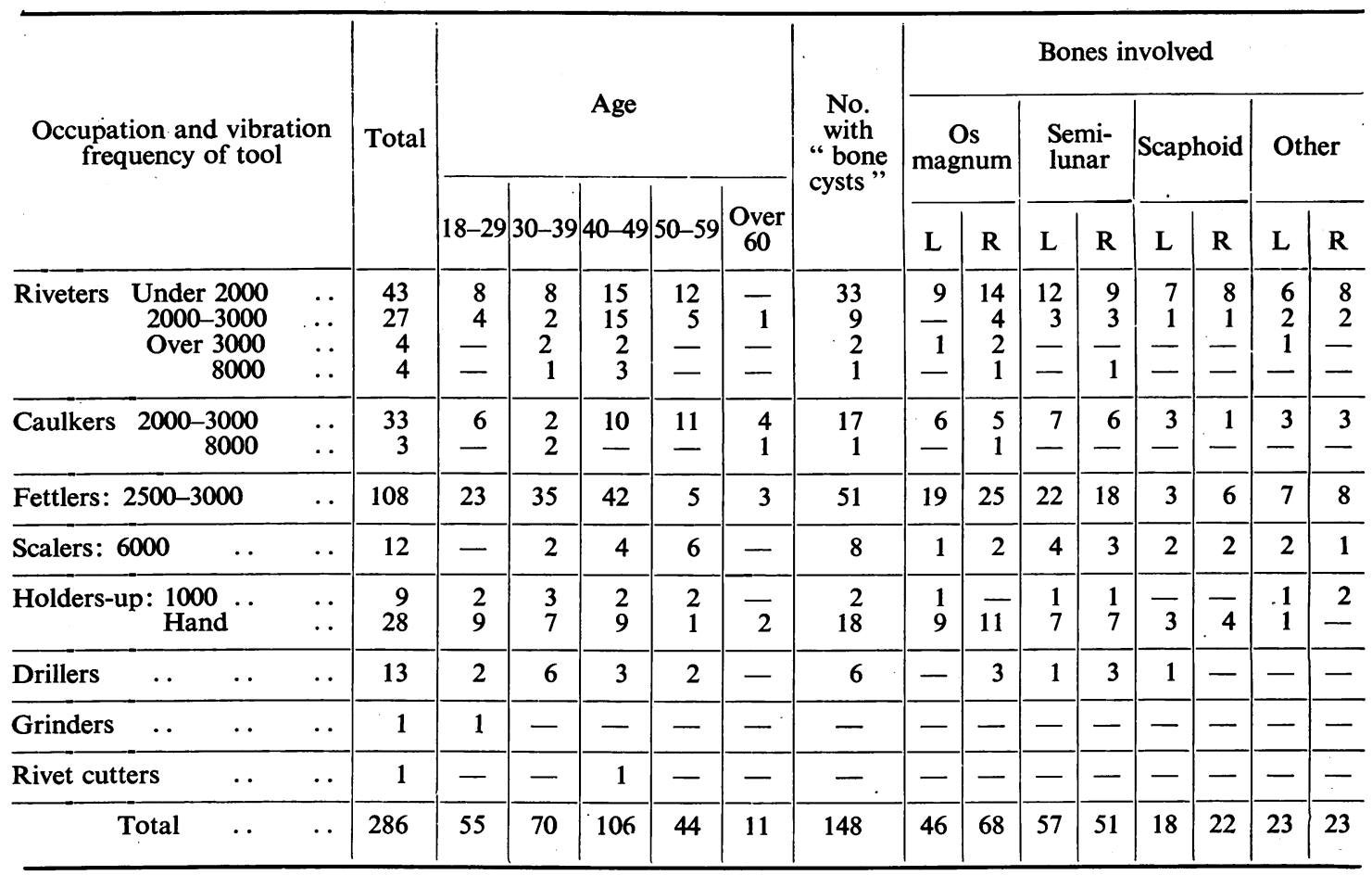


in 8 out of 12 scalers, and in 6 out of 13 drillers. The incidence of these bone cysts appears to be greater in those groups of men using tools with the lower vibration rates but it is doubtful whether this fact is significant. The individual bones of the carpus were involved in the following order of frequency: right os magnum, left semilunar, right semilunar, left os magnum and right scaphoid. The cysts appeared to have little or no connection with the age of the workers, nor with the length of time they had been engaged in handling pneumatic tools. Fracture of the scaphoid bone was found in only 7 cases, but this is a common injury not confined to pneumatic tool workers. On the whole there is little evidence to suggest that the bone cysts give rise to symptoms, or that they tend to progress and cause spontaneous fractures. During this investigation similar cysts were observed in other men engaged in many varying occupations, but who had never used pneumatic tools and who had attended medical out-patient clinics for diverse symptoms. This point has also been noted by Grout (1937) and by Kohler (1931). It seems probable, therefore, that these areas are of little significance, that they do not produce incapacity and that they are not related specifically to the use of pneumatic tools.

\section{Arthritis resulting from the use of Pneumatic Tools}

Holtzmann '(1929) first reported a case of arthritis of the shoulder arising in a pneumatic tool worker, and as a result of his work diseases of muscles, bones and joints from the use of compressed air tools were placed on the German schedule of compensatable occupational diseases. Rostock (1936) reported that in 744 Rhineland and Westphalian miners using pneumatic boring hammers arthritis of the elbow was found in 224 , arthritis of the shoulder in 3, and of the wrist in 42 cases; whereas Vossenaar (1936) examined 1000 miners who had worked for at least 10 years with the tools, taking radiographs of the elbows and wrists, and found changes in the joints in 9.8 per cent. It is to be noted that these investigations were carried out in miners who presumably were using heavy instruments with a slow vibration rate. The conditions under which mining is done are different from those under which our cases were working. Meiss, during an x-ray examination of 107 workers in Holland who had used pneumatic tools for 1-25 years, found articular changes in the head of the radius in 24 cases. He also noticed myositis ossificans on the anterior surface of the humerus at the origin of the brachialis anticus, but on the whole there was little clinical disability. Other cases of arthritis have been reported by Mauclane and Minot (1933), Sommer (1935), Sigaud and Terray (1932), Hardgrove and Barker (1933), Weber (1934), Jones (1937) and Copeman (1940) among others.

In our series the incidence of arthritis was low, and the changes were slight (see Table 4). Thus there were 9 cases among 78 riveters ( 7 of the elbow and 2 of the wrist), 9 out of 36 caulkers (all but one involving the elbow joint), 4 out of 108 fettlers ( 3 of the elbow and 1 of the wrist), 8 out of 37 holders-up ( 6 of the elbow and 2 of the wrist). Among 12 scalers there were 7 cases of arthritis and in 6 of these there were gross changes in the elbow joints.
Admittedly this group is too small to be of statistical significance and more of these workers will have to be examined before a conclusion can be reached. In the 7 cases of fractured scaphoid referred to above, arthritis of the carpus was also present.

TABLE 4

ARTHRITIS

\begin{tabular}{|c|c|c|c|c|}
\hline \multirow{2}{*}{$\begin{array}{l}\text { Occupation and } \\
\text { vibration } \\
\text { frequency } \\
\text { of tool }\end{array}$} & \multirow{2}{*}{$\begin{array}{l}\text { Total } \\
\text { No. }\end{array}$} & \multicolumn{2}{|c|}{ Arthritis } & \multirow{2}{*}{$\begin{array}{l}\text { Old fractured } \\
\text { scaphoid with } \\
\text { arthritis of } \\
\text { carpus }\end{array}$} \\
\hline & & Wrist & Elbow & \\
\hline $\begin{array}{l}\text { Riveters- } \\
\text { Under } 2000 \\
2000-3000 \\
\begin{aligned} \text { Over } 3000 & \ldots \\
8000 & \ldots\end{aligned}\end{array}$ & $\begin{array}{r}43 \\
27 \\
4 \\
4\end{array}$ & $\begin{array}{r}1 \\
1 \\
- \\
-\end{array}$ & $\begin{array}{r}5 \\
2 \\
- \\
-\end{array}$ & $\frac{1}{-}$ \\
\hline $\begin{array}{r}\text { Caulkers- } \\
2000-3000 \\
8000\end{array}$ & $\begin{array}{r}33 \\
3\end{array}$ & 1 & -8 & 1 \\
\hline $\begin{array}{l}\text { Fettlers- } \\
\quad 2500-3000\end{array}$ & 108 & 1 & 3 & 2 \\
\hline $\begin{array}{l}\text { Scalers- } \\
6000 \ldots\end{array}$ & 12 & 1 & 6 & - \\
\hline $\begin{array}{cc}\text { Holders-up- } & \\
1000 . . & \ldots \\
\text { Hand } & \ldots\end{array}$ & $\begin{array}{r}9 \\
28\end{array}$ & $\overline{2}$ & $\begin{array}{l}2 \\
4\end{array}$ & - \\
\hline Drillers & 13 & - & - & 3 \\
\hline Grinders & 1 & - & - & - \\
\hline Rivet cutters & 1 & - & - & - \\
\hline Total & 286 & 7 & 30 & 7 \\
\hline
\end{tabular}

\section{Injuries of Palmar Aponeurosis and of the Ulnar Nerve}

It has been suggested in the literature that repeated trauma may give rise to Dupuytren's contracture of the palmar aponeurosis and that this may be brought about by the use of pneumatic tools. Only one man in our series had the condition. He was a man of 47 years who had used a pneumatic chisel for 18 years. He had previously been a motor driver for 2 years and had served in the Navy for 12 years. Other men, some of whom had worked with the tools for longer periods, did not have the condition.

Seyring (1930) drew attention to the wasting of the small muscles of the hand with loss of sensation of the ulnar distribution and she thought that this was brought about by pressure on the ulnar nerve. One of our cases had well-marked ulnar paresis and 2 others had slight muscle wasting and loss of sensation, but in neither were the symptoms severe. It will be seen, therefore, that ulnar paresis can result from the use of pneumatic tools but that it is not a common occurrence.

Large bruises are commonly found on the back of the hands of riveters who work on the under-side of ships. They are caused by the hand being knocked constantly against the knee when the tool is used in an inverted position. 


\section{Summary}

A group of 286 pneumatic tool workers has been examined. The group included 78 riveters, 36 caulkers, 108 fettlers, 12 scalers, 13 drillers and 37 holders-up.

White fingers were found in 48 riveters, 27 caulkers and 77 fettlers. The syndrome usually developed after they had been on the work for from 2 to 5 years. It occurred most frequently among workers who were using tools with a vibration rate of 2000-3000 a minute. The condition occurred most often in cold weather and cold is probably a precipitating factor. White fingers rarely caused gross disability, but in three cases the condition was severe enough to make the men change their occupation.

Arthritic changes were rare and there was no convincing evidence that they can be brought about solely by the use of pneumatic tools. The possibility, however, cannot be completely dismissed.

Small areas of decalcification or bone cysts in the carpal bones were found in 35 riveters, 14 caulkers, 51 fettlers and 19 holders-up. This condition may be caused by repeated trauma, but it is not confined to workers who use pneumatic tools. The cysts cause no disability, and there is no evidence that they predispose to arthritis or fracture.

Ulnar paresis was found in three cases; but only 1 case of Dupuytren's contracture was found in 286 workers. Bruising on the dorsum of the hand occurs in riveters when driving rivets in a vertical direction.

\section{Acknowledgments}

We are indebted to Drs. M. H. Jupe and J. L. A. Grout for their help in interpreting the $\mathrm{X}$-rays; to Mr. N. J. Ferrier for taking them; and to $\mathrm{Mr}$. B. W. A. Crutchlow, H.M. Inspector of Factories, for much assistance in finding suitable factories for the investigation.

\section{REFERENCES}

Brailsford, J. F. (1934). Radiology of Bones and Joints, London, p. 27. (1936). Brit. med. J., 2, 657

Barker, N. W., and Hines, E. A. (1944). Proc. Mayo Clin., 19, 345. Bennett, G. A., Waine, H., and Bauer, W. (1942). Changes in the Knee Joint at various ages. Commonwealth Fund. New York, p. 68 .

Copeman, W. S. C. (1940). Ann. rheumat. Dis., 2, 141

Cummins, R. C. (1940). Irish J. med. Sci., 171.

Grout, J. L. A. (1937). Personal communication.
Hardgrove, M. A. F., and Barker, N. W. (1933). Proc. Mayo Clin. 8,345 .

Holtzmann, F. (1929). Z Zbl. Gewerbepath, 16, 260.

Hunt, J. H. (1936). Quart. J. Med., 19, 399.
Jones, A. R. (1937).

Junghaus, H. (1937). Arch. klin. Chir., 188, 466.

Kohler, A. (1931). Roentgenology, London, p. 17.

Kohler, A. (1931). Roentgenology, Lond

Mauclaire, P., and Minot, L. (1933). Ann. de Méd. Leg., 13, 404.

Mauclaire, P., and Minot, L. (1933). Ann. de

Meiss, W. C. (1933). Mschr. Unfallh., 40, 453.

Middleton, E. L. (1930). Ann. Rep. H.M. Chief Insp. Fact., p. 119. Mills, J. H. (1942). Northwest Medicine, 41, 282

Rostock, P. (1934). Mschr. Unfallh.

- (1936). Med. Klinik., 36, 341.

--(1937). Fortschr. a.d.get.d. Roentgenstr., 55, 21.

Seyring, M. (1930). Arch. Gewerbepath. u. hyg., 1, 359

Sigaud and Terray (1932). Gaz. Hôp., 20, 357.

Sommer, R. (1935). Beitr. klin. Chir., 161,37. Occupation \& Health

Teleky, L. (1927). Quoted from Teleky, L.

Supplement, Geneva, p. 2, Sept. 1938.
Vossenaar, A. H. (1936). 949.

Vossenaar, A. H. (1936). Echo méd. Nord., 6, 949.
Weber, F. W. A. (1934). Mschr. Unfallh., 41, 75. 